\title{
Cenzura carska wobec publikowanej korespondencji wielkich romantyków
}

Pisząc o cenzurowaniu korespondencji Adama Mickiewicza, Juliusza Słowackiego i Zygmunta Krasińskiego, należy mieć świadomość, że mamy do czynienia z kilkoma różnymi zjawiskami: po pierwsze - autocenzurą stosowaną przez poetów, po drugie - praktykami cenzurowania spuścizny epistolograficznej przez rodziny i wydawców przygotowujących do druku zbiory ich korespondencji, po trzecie kontrolą urzędów państwowych.

Autocenzura wynikała z tego, że autorzy zdawali sobie sprawę, że ich listy, zanim trafią do adresatów, mogą być czytane przez osoby postronne. Krasiński tak pisał do przebywającego na emigracji Konstantego Gaszyńskiego (Kissingen, 7 lipca 1836 roku): „Że zaś w Niemczech listy czytelników mają, o tym nie wątp, tak samo jak we Włoszech, Francji i wszędzie"'; a w liście do Henryka Reeve’a (Wiedeń, 12 kwietnia 1838 roku) napominał go, by pamiętał, że korespondencja kierowana do Polski podlega kontroli rosyjskiej policji politycznej:

A tymczasem godziny biegną, dni idą, a termin się zbliża: to znaczy, że za miesiąc wyjeżdżam stąd i wracam do Polski! Kiedy będziesz pisał do mnie do Warszawy, wspomnij na mądrą Minerwę i ten uroczy symbol starożytnych, przedstawiający Amora z palcem na ustach. Bądź klasyczny, przyjacielu! 
Także Mickiewicz, gdy zdecydował się na pozostanie na emigracji, kontakty korespondencyjne z rodakami w kraju ograniczał do minimum, utrzymując je głównie z bratem Franciszkiem Mickiewiczem i Józefem Grabowskim (mieszkańcami Wielkiego Księstwa Poznańskiego). W liście do pierwszego z nich (Bex, 10 lipca 1833 roku) pisał:

Odebrałem parę biletów, w których mię ostrzegano, żebym was listami częstymi nie nawiedzał, bo w teraźniejszych burzliwych czasach korespondencje z zagranicą obudzają podejrzenie. Wstrzymałem się od pisania, zwłaszcza że jak widzę z twoich listów, poprzednie moje pisma zaginęły; nie wiem dlaczego, bo w moich listach oprócz braterskiego pozdrowienia i kilku słów o interesach nic nigdy nie bywało ${ }^{3}$.

Zarówno Krasiński (podróżujący po Europie z paszportem rosyjskim), jak i Słowacki, pisząc do przyjaciół i bliskich pozostających w kraju, musieli być szczególnie ostrożni, aby nie narażać ich na represje władz zaborczych. W związku z tym w listach do nich kierowanych stosowali takie zabiegi, jak przemilczenia, język ezopowy, aluzje, szyfry i kamuflaże, a treści drażliwe lub niebezpieczne politycznie starali się przekazywać omownie. Przykładowo, autor Balladyny w liście do matki (Paryż, 10 grudnia 1831 roku) tak pisał o uroczystych obchodach rocznicy wybuchu powstania listopadowego, zorganizowanych w Paryżu przez Komitet Francusko-Polski pod przewodnictwem Marie-Josepha de La Fayette’a:

Obchodziliśmy rocznicę urodzin naszej kuzynki. Jedynie oglądając się na was, nie przyłożyłem się do tego obchodu tak, jakiem to sobie wprzód, nie rozważywszy dobrze zamierzył. Rej wodził na wieczorze znajomy niegdyś w Krzemieńcu tancerz dzisiaj zjedzony przez mole biblioteczne, chudy, z dwoma czerwonymi plamami na policzkach, któremu do ozdoby jeszcze wąsy przybyły ${ }^{4}$.

Dużą rolę w cenzurowaniu korespondencji poetów odegrały ich rodziny (Władysław Mickiewicz, Salomea Bécu, Eliza Krasińska i jej dzieci), obawiające się ujawnienia intymnych szczegółów z prywatnego życia poetów oraz ich opinii na temat aktualnych problemów życia społecznego i politycznego Europy, a także działalności publicznej (w wypadku Mickiewicza). Szanując ich wolę, wydawcy poszczególnych bloków korespondencji opuszczali te listy (lub ich fragmenty), które dotyczyły sfery życia prywatnego (m.in. stanu zdrowia poetów, ich rodzin i innych adresatów, a także romansów i przygód miłosnych) lub zawierały krytyczne (a często złośliwe) opinie na temat ludzi jeszcze żyjących i działających, treści o tematyce politycznej, passusy mogące skompromitować nadawcę bądź adresata.

Ponieważ na temat autocenzury i cenzury wydawców istnieje już bogata literatura przedmiotu ${ }^{5}$, toteż w tym artykule skupię się na rekonstrukcji stosunku cenzury

${ }^{3}$ A. Mickiewicz, Dzieła. Wydanie Rocznicowe, 1798-1998, t. 15: Listy, cz. 2: 1830-1841, oprac. M. Dernałowicz, E. Jaworska i M. Zielińska, Warszawa 2003, s. 221.

${ }^{4}$ J. Słowacki, Korespondencja, t. 1, oprac. E. Sawrymowicz, Wrocław 1962, s. 86. Tancerzem tym był Joachim Lelewel, a kuzynką nazywał poeta Polskę. W całej pracy, w cytatach z edycji pochodzących z epoki, pisowni świadomie nie uwspółcześniano.

${ }^{5} \mathrm{Na}$ szczególną uwagę zasługują opracowania Zbigniewa Sudolskiego: Korespondencja Zygmunta Krasińskiego. Studium monograficzne, Warszawa 1968; Odzyskane świadectwo, w: K. Gaszyński, Zygmunt Krasiński i moje z nim stosunki, wstępem oraz przypisami opatrzył Z. Sudolski, Opinogóra 2009, s. 9-16; Początki dziejów spuścizny literackiej Juliusza Słowackiego. (Na marginesie zapomnianych kontaktów rodziny poety z Karolem Szajnochą), w: Juliusz Słowacki. W stopięćdziesięciolecie urodzin. Materiały i szkice, Warszawa 1959, s. 432-451; Mickiewicz jako epistolograf, „Przegląd Humanistyczny” 1986, nr 3/4, s. 47-69; Juliusz Stowacki jako epistolograf, „Przegląd Humanistyczny” 1986, nr 9/10, s. 47-58; Główne tendencje w rozwoju epistolografii romantycznej w Polsce 
rosyjskiej do edycji korespondencji poetów z okresu od początku lat sześćdziesiątych XIX wieku do wybuchu pierwszej wojny światowej. Omówię ingerencje urzędników zarówno w nieliczne zbiory listów, które starano się opublikować w zaborze rosyjskim, jak też w edycje importowane. Opiszę wydania: 1) których w ogóle nie pozwolono rozpowszechniać; 2) które dopuszczono do obiegu warunkowo, po usunięciu niektórych fragmentów; 3) te, co do których nie było zastrzeżeń.

W badanym okresie ukazało się czterdzieści osiem wydań korespondencji poetów: dwadzieścia trzy wydania Mickiewicza (w tym trzynaście wyborów listów w wielotomowych edycjach zawierających różnorodne utwory pisarza), piętnaście wydań Słowackiego (w tym cztery edycje w wydaniach zbiorowych jego dzieł) i dziesięć zbiorów listów Krasińskiego. Najwięcej z nich opublikowano w Galicji - dwadzieścia dwa zbiory wydrukowano przede wszystkim we Lwowie (siedemnaście) i w Krakowie (pięć), a następnie za granicą - siedemnaście (w Paryżu - dziesięć, w Lipsku - cztery, w Chicago - dwa i w Naumburgu - jeden). Najmniej zbiorów wydano w prowincjach pruskich - pięć (w Poznaniu - cztery, w Mikołowie - jeden), i w zaborze rosyjskim - cztery (wszystkie w Warszawie). Pełną listę edycji zamieściłam w aneksie.

O ile jednak mieszkańcy prowincji austriackich i pruskich mogli bez przeszkód obcować ze wszystkimi tymi wydaniami, o tyle czytelnicy w Królestwie Polskim tylko z dziewiętnastoma edycjami (39,6\%), w tym w znacznej części (42,1\%) okaleczonymi przez cenzurę rosyjską.

Jeśli chodzi o korespondencję Mickiewicza, to cenzura rosyjska w jego listy prywatne: pisane do bliskich (żony, brata bądź przyjaciół), dotyczące spraw codziennych (np. bytowych czy zdrowotnych) oraz problemów związanych z rolą pisarza (np. zmagań twórczych i kłopotów wydawniczych), a także zawierające relacje i wspomnienia z podróży, ingerowała sporadycznie. Kwestionowała zwłaszcza teksty (lub ich fragmenty) poświęcone sprawom publicznym: odezwy i listy otwarte do osób pełniących funkcje urzędowe.

Pierwszy wybór korespondencji poety, opublikowany w tomie szóstym paryskich Pism, trafił do zaboru rosyjskiego już na początku lat sześćdziesiątych. Ze zbioru liczącego sześćdziesiąt trzy listy cenzura carska poleciła usunąć tylko jeden list, będący w istocie artykułem politycznym: O projekcie dziennika francuskiego (s. 419-430), stanowiącym odpowiedź - jak czytamy w przypisie - „na udzielony sobie przez Niemcewicza program do nowego dziennika francuzkiego, obronę sprawy polskiej mającego na celu”' ${ }^{6}$ Tekst

(Mickiewicz - Krasiński - Słowacki - Norwid), „Przegląd Humanistyczny” 1987, nr 2, s. 33-52. Wiele cennych uwag zawierają też wstepy i komentarze tego autora w edycjach listów Krasińskiego. O problematyce tej pisali także m.in.: P. Hertz, Uwagi o listach Juliusza Słowackiego, w: idem, Gra tego świata, Warszawa 1997, s. 52-64; Listy Krasińskiego, rozmowa z M. Zagańczykiem, w: ibidem, s. $354-$ -361; J. Pawlik-Świetlikowska, Korespondencja jako tekst sylwiczny na przykładzie listów Adama Mickiewicza, w: Sztuka pisania. O liście polskim w wieku XIX, pod red. J. Sztachelskiej i E. Dąbrowicz, Białystok 2000, s. 55-57; E. Dąbrowicz, Listy-Iustra (Pomiędzy Juliuszem Słowackim a Salomeą Bécu), w: ibidem, s. 130-131; M. Zielińska, Listy Mickiewicza, w: Mickiewicz. Encyklopedia, Warszawa 2001, s. 273-274; J. Fiećko, Rosja Krasińskiego. Rzecz o nieprzejednaniu, Poznań 2005, s. 20, 30-36, $43-44$ i in.; M. Kowalska, Warsztat wydawniczy lgnacego Janickiego, „Sztuka Edycji. Studia Tekstologiczne i Edytorskie” 2012, nr 1 (2): Dziewiętnastowieczni edytorzy i wydawcy, pod red. A. Markuszewskiej, s. 33-34; A Markuszewska, Leopold Méyet jako edytor i wydawca listów romantyków, w: ibidem, s. 41-48; E. Dą̧browicz, Poeta anonim, „Sztuka Edycji. Studia Tekstologiczne i Edytorskie” 2012, nr 2 (3): Autografy i edycje. Wokół tekstów Zygmunta Krasińskiego, pod red. M. Strzyżewskiego, s. 35-45; J. Lyszczyna, Konstanty Gaszyński - pierwszy edytor listów Zygmunta Krasińskiego, w: ibidem, s. 55-57; T. Winek, „Irydiona” boje z cenzurą, w: Literatura w granicach prawa (XIX-XX w.), pod red. K. Budrowskiej, E. Dąbrowicz i M. Lula, Warszawa 2013, s. 72-82; A. Markuszewska, Listy literackie Zygmunta Krasińskiego, „Sztuka Edycji. Studia Tekstologiczne i Edytorskie” 2014, nr 1-2 (6): Zygmunt Krasiński - edycje i interpretacje, pod red. M. Strzyżewskiego, s. 49-53; T. Winek, "Długi mój pobyt w Rosji nauczył mie zbytniej ostrożności...” Pisarze wobec cenzury w latach trzydziestych XIX wieku, „Sztuka Edycji. Studia Tekstologiczne i Edytorskie” 2015, nr 1 (7): Edytorstwo a cenzura (XIX-XX wiek), pod red. K. Budrowskiej i E. Dąbrowicz, s. 9-16; A. Markuszewska, Poetyckie światy romantyków. O młodzieńczej korespondencji Zygmunta Krasińskiego i Henryka Reeve'a, Toruń 2017, s. 50-83.

${ }^{6}$ A. Mickiewicz, Pisma, t. 6, wydanie zupełne, Paryż 1861, s. 419. 
ten cenzura zagraniczna konsekwentnie usuwała także z innych edycji importowanych, w których umieszczano go zresztą w dziale „Artykuły polityczne”. Z omawianego zbioru urzędnik polecił też wyciąć s. 405, na której znalazł się początek listu do Antoniego Edwarda Odyńca (Avignon, 22 września 1833 roku), gdzie poeta zawiadamiał przyjaciela o śmierci Stefana Garczyńskiego. Jak się wydaje, cenzorowi chodziło jednak jedynie o przypis zamieszczony na dole strony ${ }^{\urcorner}$:

W papierach Mickiewicza znajduje się własną jego ręką pisany nagrobek dla

Garczyńskiego w Avignon. Brzmi następnie:

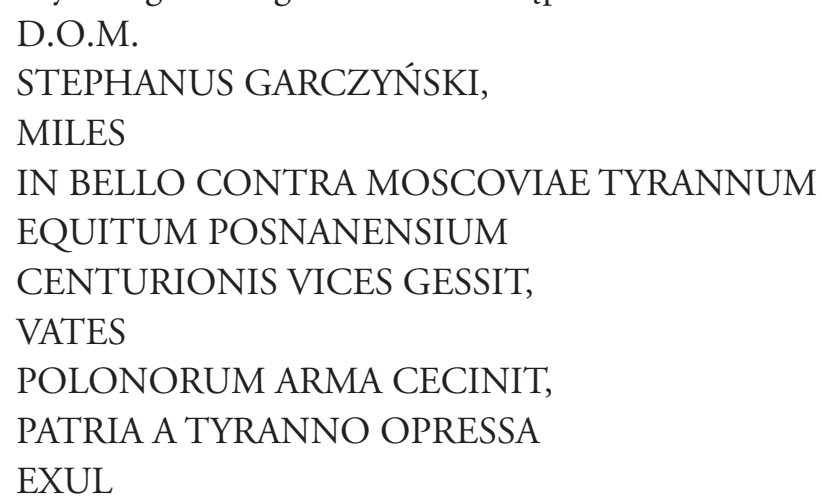

W późniejszych zbiorach korespondencji sprowadzanych do zaboru rosyjskiego przypisu tego już nie kwestionowano.

Gdy w 1867 roku próbowano wprowadzić do obiegu w Cesarstwie Listy śp. Adama Mickiewicza do Pani Konstancji, cenzor Ignacy Rogalski zaproponował dopuścić je do sprzedaży po usunięciu s. 17-18, 25, 27-28, 31-32 i 36, na których znalazło się „kilka fragmentów o charakterze politycznym" ${ }^{8}$, lecz Komitet postanowił zatrzymać całą książkę. Owych dwudziestu jeden listów nie wykreślano jednak z innych zbiorów, importowanych w latach 1873, 1876, 1881, 1897, 1899 i 1906.

Brak konsekwencji cenzura zagraniczna wykazała także, rozpatrując w latach siedemdziesiątych obszerne wybory listów, publikowane wówczas w Paryżu. W 1873 roku dopuściła najpierw do obiegu wydanie drugie Korespondencyj (Paryż 1871-1872), zawierające dwieście siedemdziesiąt pięć listów poety (tom pierwszy) i tyle samo listów pisanych do niego (tom drugi). Jednak w 1875 roku decyzję zmieniła, zakazując sprzedaży obu tomów. W tym samym roku podobnie potraktowała dwa pierwsze tomy wydania trzeciego Korespondencyj (Paryż 1875, tomu trzeciego nie sprowadzono), które zawierały niemal te same teksty co niekwestionowane przez cenzurę w 1873 roku wydanie drugie, a także tom drugi wydania pierwszego (Paryż 1872). Gdy natomiast w 1876 roku sprowadzono tom pierwszy wydania pierwszego Korespondencyj (Paryż 1870), dopuszczono go do obiegu pod warunkiem usunięcia kilku fragmentów, choć zawartość tej edycji była tożsama z zawartością edycji drugiej.

${ }^{7}$ Mickiewicz o zgonie przyjaciela pisał przecież także do innych osób (m.in. do lgnacego Domeyki), lecz informacji tej cenzura nie kwestionowała.

${ }^{8}$ Świat pod kontrolą. Wybór materiałów z archiwum cenzury rosyjskiej w Warszawie, wybór, przekł. i oprac. M. Prussak, Warszawa 1994, s. 39 . 
Na s. 75-77 urzędnik zakwestionował w całości list poety Do Redaktora „Pamiętnika Emigracyjnego" (Paryż, kwiecień 1833 roku) ${ }^{9}$, będący odpowiedzią na „korespondencję z Krakowa", atakującą zakończoną klęską wyprawę Józefa Zaliwskiego do kraju ${ }^{10}$. Mickiewicz pisał w nim m.in.:

Ludzie, którzy przez tyle krajów, skroś tylu trudności, tylu niebezpieczeństw, przedzierali się na ziemię ojczystą, szukając zemsty na nieprzyjacielu lub śmierci, ludzie ci, są już osądzeni podwójnym sądem wojennym, sądem Mikołaja jako najstraszniejsi jego nieprzyjaciele i sądem przysięgłych, równych sobie duszą i powołaniem żołnierzy emigracyi, którzy zazdroszczą ich śmierci, którzy słysząc, że broń jeszcze raz dobyto na ziemi polskiej, klną swojej niedobrowolnej bezczynności ${ }^{11}$.

Z listu poety do gen. Jana Z. Skrzyneckiego (Paryż, 7 kwietnia 1842 roku) polecił zaś usunąć fragment (wyróżniony przeze mnie gwiazdkami):

Bo wątpię żebyś odpowiedział językiem teraźniejszych faryzeuszów, *że religja swoją drogą a polityka swoją drogą. Toż i Mikołaj gada w katechizmie nowym: „dziatki módlcie się, spowiadajcie się, ale mnie służcie”, a dziatki ze spowiedzi, z rozmowy z Bogiem i tyle się nie dowiadują że djabłu służą. Walczą z Andrzejem za Chrystusa!* (s. 190) ${ }^{12}$.

Jednocześnie nakazał wykreślić passus z zamieszczonej w przypisie (s. 189) odpowiedzi Skrzyneckiego (Bruksela, 12 kwietnia 1842 roku) na ów list:

Naprzeciw władzy która jest wcieloną zbrodnią, bunt jest powinnością świętą. Widzisz że modlitwa i spowiedź nie zwróciłyby mnie z drogi, lecz pomogły, utwierdziły, wzmocnity i oświecity, nie tak jak drugich, którzy wymodliwszy się podobni są do tych co chorując, lekarstwami się przepełnili i chorują jeszcze na Siechtum. To co Andrzej zamierza i do czego jak powiada ma missję, to należy dopełnić naprzód na drodze dyskusji i przedstawień z Rzymem: kościołowi Paraclet jest obiecany w miejscu i czasie, nie odrzuci go pewno w osobie Andrzeja jeżeli missję swoję odnowienia chrystjanizmu udowodni, a dopiero potem kiedy go Rzym odrzuci, mocny udzieloną mu z góry missją może przystąpić do buntu: ta jest zdaje mi się naturalna droga rozsądku, prostoty i czystości zamiaru. Jeżeli zaś idzie tylko o ratowanie ojczyzny, wtenczas to rzecz inna. - Andrzej zanadto dużo ma rozsądku aby tej prostej drogi nie widział i nią nie poszedł, inaczej, jak to mówią w naszem kraju: „wszystko się to o Bożą mękę rozbije".

${ }^{9}$ W ostatnim wydaniu jubileuszowym tekst ten (pt. Do Redaktora "Pamiętnika Emigracji”) zamieszczono nie w Listach, lecz w Uzupełnieniach do Pism politycznych z lat 1832-1834; A. Mickiewicz, Dzieła. Wydanie Rocznicowe, t. 6: Pisma filomackie. Pisma polityczne z lat 1832-1834, oprac. M. Witkowski, Cz. Zgorzelski, przy współpracy A. Paluchowskiego, Warszawa 2000.

${ }^{10}$ Wzmiankę o tym wydarzeniu zakwestionowano również w liście Józefa Bohdana Zaleskiego do syna poety, zamieszczonym w sprowadzonym do zaboru rosyjskiego w 1881 roku tomie drugim wydania czwartego Korespondencyj (Paryż 1875, s. 114-116) W zdaniu brzmiącym „Po niefortunnej *wyprawie Zaliwskiego, rozpostarły się i w Polsce okrutne Mikołajowskie prześladowania i katusze ${ }^{\star \prime \prime}$ polecono wykreślić fragment wyróżniony przeze mnie gwiazdkami.

${ }^{1}$ A. Mickiewicz, Korespondencya, Paryż 1870, s. 77.

${ }^{12}$ Ów „katechizm nowy” to Katechizm o czci cesarza wszech Rossyy, czyli objaśnienie czwartego przykazania Boskiego w stosunku do zwierzchności kraiowey. Za najwyższym rozkazem dla użycia po szkołach i kościołach rzymsko-katolickich w Rossyy, wydrukowany, Wilno 1832. Jak pisze Janina Bieniarzówna (Kłągiewicz Andrzej Benedykt, w: Polski słownik biograficzny, t. 13, Wrocław 1967-1968, s. 41), „głośną była w Wilnie sprawa "Katechizmu o czci cesarza wszech Rossyi« (1. wyd. 1832) przeznaczonego do użytku w kościołach i szkołach wiejskich, za co czyniono odpowiedzialnym K-a". 
Ostatnia ingerencja dotyczyła opublikowanego w przypisie na s. 312-313 żartobliwego wiersza Juliana Uursyna Niemcewicza, który wykreślono w całości:

\section{DO DZIESIĘCIOMIESIĘCZNEJ DZIEWCZYNKI ŚLICZNEJ MARYSI MICKIEWICZÓWNEJ, DYTYRAMBA}

Cudo piękności, Niebios arcydzieło, Zkądżeś się wzięło?

Czyś z różnych od nas stworzona żywiołów,

Czyś z legjonu uciekła aniołów,

Nie wiemy: toć nam przecie nie jest tajnem

Żeś stworzeniem nadzwyczajnem.

Kto cię widzi, kto słyszy, z podziwu obsłupia,

Przy tobie Venus brzydka i Minerwa głupia.

Jeśli z latami i powaby wzrosną

Jak mamy tego nadzieje,

Wszyscy dla ciebie z miłości poschną

I cały świat oszaleje.

Nie czyń jak Venus, co na górze Idzie

Prostego sobie wybrała pastucha,

Taka zniewaga na ciebie nie przydzie;

Ty wyniosłego posiadając ducha,

Śmiało po pysznych deptać będziesz Panach

I carów wodzić w kajdanach.

$\mathrm{O}$ wieszczbie mojej nie wątpij ni trocha,

Wierz car się w tobie zakocha.

Dla ciebie w pośród frejlin swoich tłumu

Szaleć, odchodzić będzie od rozumu,

Jeśli wtenczas z uśmiechem do ciebie się zbliży

Zacznie umizgać, pokornie się zniży,

Powiedz mu, znam ja twą zemstę zawziętą

I twoję chytrość przeklętą.

Próżno się płaszczysz, wychwalasz me wdzięki

Nie dam ci nawet pocałować ręki,

Aż nam powrócisz matki ukochane,

Ojce i dzieci na Sybir zesłane,

Aż się w swej złości szalonej ukrócisz

I Polskę całą nam zwrócisz.

Pierwsze paryskie wydanie Korespondencyj ponownie sprowadzono do Królestwa w 1906 roku. Tym razem cenzura oba tomy dopuściła do obiegu bez skreśleń.

Największy wybór listów poety czytelnicy w zaborze rosyjskim mogli poznać ze sprowadzonych w 1881 roku trzech tomów wydania czwartego Korespondencyj (Paryż 1874-1875), zawierających czterysta pięćdziesiąt sześć listów, oraz z czterech tomów (7-9 i 11) Dziet poety (Paryż 1881), gdzie opublikowano ich blisko o sto więcej.

W obu edycjach ingerencji było jednak niewiele. Poza utworami wspomnianymi wcześniej (wierszykiem do Marysi Mickiewiczówny i fragmentem listu do Skrzyneckiego), 
zakwestionowano w nich w całości także dwa inne teksty, wcześniej niepublikowane. Pierwszy to Akt w sprawie Mirskiego, będący odpowiedzią na list otwarty Światopełka T.T. Mirskiego, który

[...] obwieszcza, iż wyjednał sobie przebaczenie cesarza rosyjskiego, przeszedł z wiary katolickiej na schyzmę i spodziewa się, że inni emigranci polscy pójdą w jego ślady ${ }^{13}$.

Pismo Mickiewicza podpisało ponad pięćdziesięciu znanych emigrantów (ich nazwiska oczywiście też pominięto), którzy czyn Mirskiego potępili, określili go bowiem m.in.:

Jako wysoką zdradę przeciwko Narodowi Polskiemu, który myśl pańską złożoną w wierze i nadziejach swoich święcie dochowuje;

Jako potwarz przeciwko emigracyi, która posłannictwu narodowemu wiernie dotrwa;

Jako obelgę przeciwko całemu plemieniu słowiańskiemu, które wszelką zdradą się brzydzi ${ }^{14}$.

Drugi wykreślony list, adresowany do redakcji dziennika „Demokrata Polski”, zamieszczony jako Oświadczenie w sprawie Pilchowskiego, dotyczył podobnej sprawy. Poeta ujawnił w nim i surowo potępił byłego towiańczyka Seweryna Pilchowskiego za zamiar poddania się Rosji i przejścia na prawosławie.

Ponadto we wszystkich omówionych edycjach kilkanaście listów opublikowano z niewielkimi opuszczeniami, przy czym część z nich z pewnością nie wynikała z przyczyn cenzuralnych. Zdarzało się bowiem, że wydawca albo nie dysponował pełnymi tekstami listów ${ }^{15}$, albo celowo pomijał niektóre ich fragmenty, gdyż dotyczyły intymnych sfer życia (np. choroby Celiny ${ }^{16}$ czy zawikłanych stosunków poety z rodziną Ankwiczów ${ }^{17}$ ).

Względy cenzuralne zaś zadecydowały prawdopodobnie o braku niektórych passusów w kilku listach adresowanych do Odyńca. Chodzi o listy publikowane w 1860 roku w „Kurierze Wileńskim”. Jak się wydaje, fragmenty te usunął miejscowy urząd,

${ }^{3}$ A. Mickiewicz, Korespondencya, wyd. 4, t. 2, Paryż 1874, s. 158.

${ }^{4}$ Ibidem.

${ }^{15}$ Przykładowo w liście do Feliksa Wrotnowskiego (Paryż, 26 maja 1841 roku) brakowało zakończenia: „Można pisać uwagi nad lekcją jakie chcąc, ale przytaczacie wyrazy jak gdyby moje własne, do których ja nie mogę przyznać się"; A. Mickiewicz, Dzieła. Wydanie Rocznicowe, t. 15, cz. 2, s. 622.

${ }^{16}$ W liście do Celiny Mickiewiczowej (Paryż, pierwsza połowa 1839 roku) wydawca opuścił następujący fragment: „Doktorowie dlatego tylko jeszcze cię zatrzymują, że teraz właśnie czas nadchodzi twojej kobiecej choroby, a niezmiernie jest ważną rzeczą, aby[ś] ten czas w spokojności przeżyła"; ibidem, s. 448.

${ }^{17} \mathrm{Na}$ przykład w liście do Odyńca (Paryż, 2 lipca 1834 roku) pominięto m.in. następujący fragment: „Jeślibyś pisał kiedyś do p. A., daj jej do zrozumienia i napisz te słowa ode mnie, "że Mickiewicz pisać zapewne nie będzie, bo interesu nie ma i mieć nigdy nie spodziewa się, a listami etykietalnymi nie chce sobie i nikomu czasu zabierać«. Nie wiesz, jak mnie p. A. dręczyła; jej korespondencja była jak dawniejsze postępowanie: ilekroć uciekałem, nęciła półsłówkami i obietnicami, a kiedym czulej przemówił, znowu rejterowała się i tylko prawiła grzeczności. Dawno już czułem, że ta rodzina tyle mi dokuczyła, że nawet chociażby już mnie szukano nie miałbym serca zbliżyć się do niej. Zal tylko bardzo H. - Wiem, że ją ta wiadomość zasmuci"; ibidem, s. 269. Z wcześniejszego zaś listu do niego (Rzym, 19 listopada 1830 roku) usunięto passus: „Zdrowie H. bardzo w złym stanie i smutną zgaduję przyszłość. Głupi rodzice, jeden dziwna oziębłościa, druga zbytnią troskliwością zapewne ją domęcza. Nie uwierzysz jak ją po jeziorach i górach włóczyli!"; ibidem, s. 79. Jak wiadomo, Mickiewicz poznał rodzinę Ankwiczów podczas pobytu w Rzymie i między nim a Henryką doszło do pewnej zażyłości, której nie sprzyjali rodzice panny - Stanisław Ankwicz i Zofia z Łempickich - gdyż przyszłego zięcia upatrywali w sferach arystokratycznych. Ten ostatni list syn poety wydrukował w całości w Dziełach (t. 7, Paryż 1880, s. 75), lecz określenie „głupi rodzice" zamienił na "nieopatrzni rodzice”. 
a późniejsi wydawcy, nie znając oryginałów, lecz tylko owe pierwodruki, po prostu nie uwzględnili ich w swoich edycjach. Oto kilka przykładów. W liście datowanym „Paryż, 8 grudnia 1832 roku” zabrakło fragmentu zdania (wyróżniam go gwiazdkami): „Drukowałem tę broszurkę stylem biblijnym *pod tytułem Księgi narodu i pielgrzymstwa polskiego*, wkrótce mieć ją będziesz", a w zdaniu (dotyczącym Pana Tadeusza): „Podoba się bardzo szlachcie powstańczej”, określenie „powstańczej” przekształcono na „tutejszej”, co zupełnie zmieniło sens wypowiedzi. W liście pisanym z Paryża 28 stycznia 1833 roku nie zamieszczono z kolei następującego passusu:

Dziady na emigracji zdaje się, że niewielkie zrobiły wrażenie. Księgi pielgrzymstwa obudziły hałas w różnych kierunkach. Ja Dziadów 2000 egzemplarzy przedałem za dwa tysiące franków i bardzo jestem rad z tego. Miałem za co żyć...

O ile fragmenty te cenzura wileńska zakwestionowała prawdopodobnie dlatego, że jest w nich mowa o utworach zakazywanych w zasadzie przez cały badany okres, o tyle powodem usunięcia fragmentów innych listów mogły być czytelne aluzje do sytuacji w kraju po powstaniu listopadowym. Na przykład z jednego z listów (Paryż, 23 maja 1833 roku) usunięto następujące passusy:

Pisałem do Grabowskiego dwa razy, nie mam odpowiedzi i nie wiem, co się dzieje z moim bratem. [...] Piszesz, że ciebie do Litwy wzywają. Ja nie byłbym przeciwko temu, tylko skąd pewność, że cię nie wpakują gdzie w dziurę. Tam bliżej, lepiej sam musisz wiedzieć; radź się więc Boga i twego serca [...],

a z innego (Bex, 10 lipca 1833 roku) - pytanie poety: „Co się stało z twymi projektami wyjazdu do Poznańskiego".

Jeśli chodzi o pozostałe edycje zawierające korespondencję, to nigdy legalnie do rąk czytelników w Cesarstwie nie trafił (opublikowany przez syna poety w dwóch tomach) wybór dokumentów z okresu towianizmu zatytułowany Wspótudziat Adama Mickiewicza w sprawie Andrzeja Towiańskiego (Paryż 1877), obejmujący przede wszystkim listy, a także przemówienia i pisma organizacyjne towiańczyków. Publikację tę próbowano sprowadzić w 1879 roku, lecz cenzura zakazała jej rozpowszechniania.

Bez ingerencji dopuszczono natomiast w 1899 roku Wybór listów wydany w tymże roku w Krakowie z myślą o czytelnikach w Cesarstwie, o czym pisał otwarcie we Wstępie Józef Kallenbach:

aby Wybór listów mógł być czytany wszędzie, w jak najdalszych stronach [...]. Z tego względu wydawca zmuszony był pominąć niejeden ważny list albo też ten i ów podać w skróceniu ${ }^{18}$.

Trudno rozstrzygnąć, z czego wydawca świadomie zrezygnował, ale niewątpliwie czternaście listów ${ }^{19}$ (na sto dziewięćdziesiąt zamieszczonych) dostosował do wymogów rosyjskiej cenzury zagranicznej. Przykładowo, w przywoływanych wcześniej listach

${ }^{18}$ A. Mickiewicz, Wybór listów, ułożył J. Kallenbach, Kraków 1899, s. V.

${ }^{19}$ Listów opublikowanych w formie niepełnej było nieco więcej, trudno jednak stwierdzić, czy Kallenbach skrócił je celowo, czy tylko powielił ich wersje z edycji wcześniejszych, o których była mowa wyżej. 
do Odyńca pominął przypisy zawierające łaciński napis na nagrobku Garczyńskiego (Awinion, 22 września 1833 roku) i żartobliwą odę Niemcewicza (Domont, 18 lipca 1836 roku), a w korespondencji do Wiktora Jundziłła (Paryż, 23 lutego 1841 roku) zamienił określenie „stronnik Moskwy” na „stronnik Rosyi”. W sześciu innych listach wydawca wykropkował kilka krótkich fragmentów (wyróżniam je gwiazdkami), m.in. w liście do Ignacego Domeyki (Poznań, 4 stycznia 1832 roku): „Ale powrócić! *widzieć co się tam dzieje!*”20, a w liście do Bohdana Zaleskiego (Paryż, 8 maja 1839 roku): „Inaczej *zepsieje do reszty w Paryżu*”21. Zdarzyło się też, że jeden z usuniętych passusów pomysłowo zakamullował: w liście do Domeyki (Paryż, 7 maja 1841 roku) w zdaniu „ ${ }^{*}$ Chociaż w kraju okropna bieda i ciągle wiążą, jest wielu, którzy ledwie by do piekła nie poszli, aby tylko z emigracji wydobyć się"22, słowo „jest” wydrukował bowiem dużą literą, sugerując, że owo zdanie zaczyna się właśnie w tym miejscu.

Opuszczeń dłuższych fragmentów Kallenbach zazwyczaj nie zaznaczał. Oto przykład jednego z takich passusów, pochodzący z listu do Zaleskiego (Paryż, 23 czerwca 1841 roku):

A co tam się dzieje w kraju! Miałem nowiny. Był u mnie jeden dawny znajomy, który objechał Rosją i Litwą. Nigdy jeszcze terroryzm taki nie pustoszył naszej ziemi. Wszyscy Polacy tamtych prowincji mogą być uważani jako mis hors la loi, to jest wyrażenie tego cudzoziemca. Płakał on i bladnąt, opowiadając. Kilku doktorów siedzi w Wilnie w kajdanach za to, że w klinice przechowywał się był ktoś podejrzany. Gmach uniwersytetu cały zamieniono na więzienie. Kolonie mają wyludnić okolice Wilna i Grodna. Aż do Bugu i Wisły ma być wytępione wszystko, co polskie. Austria i Prusy zaczynają się trwożyć. - Jeśli nie masz listów z waszych stron, nie dziw się, bo nie masz wyobrażenia, jaki tam strach, zwłaszcza na osoby podejrzane. Nawet te wiadomości zachowaj u siebie, bo przyrzekłem milczeć, póki ów cudzoziemiec nie wróci do Szwecji, swojej ojczyzny. Ma jeszcze być w Odessie i jest śledzony mocno. Gabinety coś knują o Księstwie Warszawskim, ale o nas ani myślą! Biada nam Litwinom i wam Rusinom, i tylko w Bogu nadzieja i w patronach Polski, jeśli jeszcze w nas poznają swoich rodaków ${ }^{23}$.

Również bez skreśleń dopuszczono do obiegu w 1909 roku Nieznane pisma Adama Mickiewicza. Z archiwum filomatów, zawierające m.in. opublikowane wówczas po raz pierwszy dziewięćdziesiąt pięć listów ${ }^{24} \mathrm{z}$ lat 1817-1823.

Ogólnie rzecz biorąc, mimo ingerencji cenzury czytelnicy w Cesarstwie mogli poznać w badanych latach niemal połowę odnalezionych do dziś listów poety.

Także na początku lat sześćdziesiątych do zaboru rosyjskiego trafiły Wyjątki z listów Zygmunta Krasińskiego przygotowane przez Gaszyńskiego, a wydane nakładem Księgarni Polskiej w Paryżu w listopadzie 1859 roku. W edycji tej, zawierającej spreparowane fragmenty listów do Gaszyńskiego, Delfiny Potockiej, Słowackiego, Stanisława Małachowskiego, Augusta Cieszkowskiego oraz dzieci, w nagłówkach podano jedynie

\footnotetext{
${ }^{20}$ A. Mickiewicz, Dzieła. Wydanie Rocznicowe, t. 15, cz. 2, s. 129.

${ }^{21}$ Ibidem, s. 467.

${ }^{22}$ Ibidem, s. 619

${ }^{23}$ Ibidem, s. 625.

${ }^{24}$ Publikacja ta zawierała też dwadzieścia jeden drobnych utworów poetyckich z okresu młodzieńczego oraz trzydzieści trzy pisma organizacyjne dotyczące Towarzystwa Filomatów.
} 
daty roczne i usunięto nazwiska adresatów. Pominięto też wszelkie aluzje osobiste i intymne wypowiedzi poety. Decyzje swe wydawca tłumaczył we wstępie:

Pragnąc aby ta książka mogła bez przeszkody krążý po całym obszarze dawnych ziem polskich, musiano temczasowo usunąć z niej wiele ważnych i znakomicie pięknych listów. Z wszystkich zaś innych zamieszczono jedynie główne ustępy stanowiące pewną całość artystyczną 25 .

Mimo takich środków ostrożności cenzura zagraniczna nakazała usunąć z książki następujące strony: 8, 42-44, 124-125, 215-216. Na pierwszej z nich znalazła się kompilacja dwóch listów do Gaszyńskiego, oznaczonych nagłówkiem „Genewa, 1832”, oraz fragment listu do niego datowany „Rzym, 1833 r.” Jak się wydaje, całą stronę zakwestionowano w sposób mechaniczny, gdyż chodziło tylko o następujący passus, pochodzący z listu pisanego 27 marca (początek ingerencji zaznaczyłam gwiazdką):

Prawda jest najwyższą poezyą - szumność jest pianą z której kilka farb się dobywa, ale za pier*wszym powiewem nikną i po nich na wieki! Religia jest skrzydłem którego cień na poezyą wiecznie zlewać się winien. Patrz! Od religii, od Krzyża Chrystusowego odstępuje ziemia; - ale powiedźcie mi wszyscy kędyż nowy ołtarz się zjawił? Kędyż klęknąć mam przed nowym bóstwem? Teraz nam Polakom, trzymać się Krzyża przystoi...

Fragmenty zamieszczone na s. 42-44 także pochodzity z korespondencji do Gaszyńskiego:

- pierwszy z nich, z listu oznaczonego „Kissingen, 1837”, dotyczył rozważań poety na temat sojuszu ludu ze szlachtą i bezrefleksyjnego przyjmowania cudzych rozwiązań:

Właśnie dziś *w szlachcie ocalenie Polski - w pogodzeniu się jej i pojednaniu z ludem wiejskim jedyny zaród siły - w przewodniczeniu jej nad tłumami jedyny zakład przyszłej lepszej doli. Kto zamierza ją wyrznąć, ten nędznie jest głupim - ten niewiniątkiem większem niż dziecko u piersi - ten nie ma wyobrażenia o rzeczach - ten gada próżne słowa, a powietrze samo winno mścić się nad nim że je niepotrzebnie porusza.

Uważałem ja często że to co zowią pedanteyą, gubi wiele głów i serc na tym świecie. Gdzieś się coś stało - dzięki Bogu, jest na czem się oprzeć, gotowe jest prawidło: jurare in verba magistra. Oto dewiza naszych republikanów! Przyznaję im że łatwiej baranim torem iść na oślep za czemciś lub kimciś, niż własną prawdziwą sobie obrać drogę. Ale łatwość nie jest narzędziem dobrem w ręku człowieka - palce od niej mięknieją i woskiem się stają. Praca myśli i rąk to jest przeznaczenie ludzi. U nas wielkie panuje lenistwo - wiara nasza często bywa lenistwem a nie uniesieniem. To tylko prawdą dla narodu być może co wypływa z jego historyi, co wyrosło na jego polu jak zboże lub sośniny. Ktoby cukrową trzciną chciał Mazowsze zasadzić

${ }^{25}$ Z. Krasiński, Wyjątki z listów [...], t. 1, z przedmową K. Gaszyńskiego, Paryż 1860, s. IV. 
byłyby szalonym - niemniej szalonym kto cudzemi politycznemi sposoby chce w Polsce działać; cukru z tego nie będzie!...26

- w drugim zaś, z listu oznaczonego nagłówkiem „Wenecya, 1838”, Krasiński dzielił się z przyjacielem refleksjami na temat kwestionowanego przez cenzurę carską Anhellego Słowackiego:

Czy czytałeś nowy poemat Słowackiego, Anhelli? Piękne to dzieło, z wielką sztuką wypracowane - styl przejrzysty, spokojny, kryształowy - myśl prawdziwa. Anhelli, to pokolenie które przemarnieje w łzach, w boleści, w daremnych żądzach - a umrze dnia poprzedzającego dzień w którym te ich żądze dopełnić się mają. Ten Anhelli taki samotny, taki opuszczony, patrzący na śmierć wszystkich swoich, jest doskonałym symbolem poetycznym naszego przeznaczenia. Naprzód to co Boga ma w sobie, to co najwznioślejsze, entuzyazm, prawda, miłość wielkich rzeczy, pod postacią proroka Szamana, umiera. Zostaje się jeszcze Anhellemu jakaś osłoda ludzka, pokutnica siostra Ellenai. Ale człowiek taki nawet pociechy ludzkiej długo mieć przy sobie nie może, - umiera i siostra. Ta śmierć jej, po mistrzowsku, z boską prostotą opisana. Sam już teraz, zupełnie sam Anhelli, bo wszyscy współwygnańcy pozabijali się, zatracili się, zginęli; - duszno mu i tęskno. Ostatnią mu towarzyszką został anioł Eloa, stworzony przez Alfreda de Vigny, a przez Słowackiego zagnany na śniegi biegunowe - anioł urodzony z łzy Chrystusa na Golgocie - anioł litości co się dał uwieść szatanowi - anioł co teraz grzebie kości pomarłych na błoniach białych oświecanych przez zorze polarne. Ten anioł, drugi raz się urodził w ręku Słowackiego.

Anhelli nareszcie sam skłoniwszy głowę, ducha oddaje; - aliści ledwo skonał, pędzi rycerz na koniu, rycerz podobny do zjawisk Apokalipsy, wołający piorunowym głosem: „do broni!”. Ale Eloa rzecze mu: „Jedź dalej, Anhelli już umarł - już on mój na zawsze". Taki koniec. Nieznam nic smętniejszego, nic poetyczniej pomyślanego i wykonanego. Trudno było w elegią smętną a jednak pełną barw Moorowskich przetworzyć Sybir; - poeta tego dokazał. Jeśliś nie czytał, dostań; - jeśliś zaś już miał w ręku to dzieło, powiedz co myślisz, czy toż samo co ja? Wiem, że po przeczytaniu tego utworu, zapadłem jakby w sen magnetyczny i wyśniły mi się wszystkie gwiazdy, wszystkie tęcze o których tam mowa - gwiazdy i tęcze, nie takie jak u nas, ale podobne do świateł nicość oświecających, gdyby można pojąć świat nicości ${ }^{27}$.

Następny zakwestionowany fragment (s. 124-125) pochodził z - opatrzonego nagłówkiem „Munich, 1842” - listu do Potockiej ${ }^{28}$, zawierającego refleksje poety na temat roli jednostek w historii:

Każdy czując w sobie ducha ludzkiego duszności (angoises), i to o czem duch ten wie że go Pan *nie opuści, pomyłkę taką popełnia: że to czucie, wspólne wszystkim, uważa za osobne, za swoje tylko - za ściśle indywidualne; i będąc tylko cząsteczką tego wielkiego ogólnego drgania myśli wszystkich ludzi, stawia się za ogół, występuje jak gdyby był całkowitym jej tęsknot wyrazem i dopełnionym objawią sposobów

${ }^{26}$ List napisany 6 sierpnia.

${ }^{27}$ List napisany 18 listopada.

${ }^{28}$ Według Sudolskiego (Z. Krasiński, Listy do Delfiny Potockiej, t. 1, oprac. i wstępem poprzedził Z. Sudolski, Warszawa 1975 s. 453) list ten najprawdopodobniej pisał poeta w styczniu-marcu, gdyż w kwietniu opuścił Monachium. 
zaradzenia tym bólom. Taki jest prorokiem fałszywym, pustym, czczym, do domu waryatów przeznaczonym. Zupełnie, w prawdziwym Bożym posłanniku, inaczej rzecz ta się odbywa. Ten dopiero jest wszechpojęciem w sobie, wszystkich pojęć czasu swego, wszechzlaniem w sobie wszystkich jego cierpień, i wszechobjawieniem wszystkich nieznanych lekarstw na nie. Pierwszy był cząsteczką, która chciała udawać całość; drugi jest istotną, rzeczywistą catością, która się rozleje na wszystkie cząstki, ubłogosławi je zbawieniem! Ojciec nasz niebieski skąpy w takich synów swoich lub posłanników anielskich natchnionych, bo Syna jednego ma tylko, i ten już przeszedł przez tego planetę; a przez ciąg wieków kilku nam tylko ukazał proroków i aniołów - Platona przed Chrystusem - i Sokrata, którzy nieśmiertelność obiecali ludziom i pierwsi nauczyli ich że duchami są. Po Chrystusie dał, w chwili zguby, jednego z Serafinów swoich na chwil kilka Francyi - Johannę d'Arc. Zresztą, nigdzie nie widział pewnych w historyi, bożem piętnem niezbitem, jasnem, naznaczonych objawów lub posłanników. Ale pełno jest podrzędnych, którzy się snują jak mary w bladym zmierzchu, i w takiej niewyraźności form, że nie można ich dokładnie ocenić. W tym gatunku był sławny Jakób Boehm, w Niemczech - Swedenborg i wielu innych. Władza przeczuwania przyszłości sercem lub przedmyśliwania jej rozumem, użyczoną jest wspólnie wszystkim, i na to osobnego natchnienia nie potrzeba. Ztąd wypada, że wiele proroctw może się spełnić, a ci z których wyszły, nie są jeszcze Boga prorokami - cząstka także zarwać coś może z wiedzy i z potęgi całości! - Ale tylko ten który całość ducha planety tego mieści w jednem sercu swojem, wystąpić może jako reformator prawdziwy i oznajmiciel dalszych tego świata losów! $\mathrm{Na}$ to trzeba by Bóg stworzył człowieka, któryby ducha siłą równy był duchowi całej ludzkości. Wielcy ludzie, bohatyry, wieszcze, są to duchy pojmujące całość ludzkich potrzeb i cierpień i losów, ale tylko pod tą szczególną lub ową formą, jak np. wszystkie potrzeby ludzkie w polityce pojęte przez jednego, zowią się Napoleonem.

Wreszcie na ostatnich zakwestionowanych stronach (s. 215-216) znalazła się kompilacja listów do Małachowskiego oznaczonych nagłówkiem „Nicea, 1846”. Zawierały one rozważania Krasińskiego dotyczące:

- konieczności uwłaszczenia chłopów polskich i krytyki komunizmu jako idei wschodniej:

Komunizm szaleństwem! Stan komunistyczny państwa, może być celem, ku któremu cięży historya świata, ale to chyba jako najwyższy stan społeczny. I dla tego, by nie być najstraszniejszą ironią najszaleniejszym despotyzmem, musi nastać dopiero w dni owe, gdy Chrystusowe oświecenie wszystkich uświęci. Po prostu to reguła klasztorna, do społeczeństwa całego zastosowana. Dziś pyta, czy ją można, czy podobna zastosować i czy ją lud zrozumie? Lud właśnie tylko własność zrozumie, bo jej pozbawion, a nie wyzucie z wszelkiej własności!... Trzeba przyjąć za zasadę prawo, własność nadające włościanom, gruntów przez ich posiadanych i uprawianych - to trzeba uczynić i nic więcej. Polska na tej zasadzie wywalczona, policzyłaby się z żywiołami w niej dotąd istniejącemi, i pokazałoby się wtedy, które mają prawo do życia, a które nie - co żywem jest, a co umarłem. Komunizm to idea raczej wschodnia niż zachodnia; Polski zaś przeznaczeniem zachód ze wschodem zlać w jedną równowagę w sobie, i tem samem być środkiem równowagi Europejskiej, kluczem sklepienia Europejskiego. Wrażenie wywarte przez zarys ten orientalny, rzucony do 
proklamacyi na Europę i zachód, nie dobry; - wzmianka o Bogu bez Chrystusa, musi oburzyć katolików, a chyba tylko Żydom się podobać; - bo i tych co wierzą w dalszy rozwój religii, nie zaspakaja ${ }^{29}$.

- błędów popełnionych w czasie rewolucji 1848 roku (w nawiązaniu do konfederacji barskiej):

Krzykacze wszystko zgubili. Rozpowiadali przed wszystkiemi świata policyami głośno zamiary swe, a brudne zamiary. Rządy wszystko wiedziały, skorzystały i na użytek haniebnie obróciły!... Przypomnij sobie że tak chciano, przed laty, wytępić konfederacyą Barską w samym zawiązku. Zginęło wielu pod hajdamackim nożem... Piekłem dla nas zwie się ten świat i każden dzień jego... ${ }^{30}$

- niechęci demokratów polskich do poszukiwania swojej drogi i skłonności do naśladowania wzorów francuskich (motyw ten pojawił się zresztą już wcześniej w cytowanym fragmencie listu do Gaszyńskiego):

W 1912 roku nie dopuszczono do obiegu wydanych w tymże roku we Lwowie Listów do Stanistawa Egberta Kożmiana
Czyż nasi demokraci pozbawieni pojęcia narodowości? Czy tak już zaprzęgli się w małpiarstwo doktryn franzuzkich, że nic ich odwołać do czystej myśli polskiej nie zdoła. Doktrynery także; - wolą teoryą swą, niż życie, i życia wypadki żywe - miękkość to Sławiańskich umysłów, naśladować tylko umiejących, a nigdy tworzyćc ${ }^{1}$.

Niemal te same fragmenty (na stronach 7, 38-41, 116 i 201-203) cenzura zagraniczna poleciła usunąć ze sprowadzonych także w latach sześćdziesiątych Wyjątków z listów Zygmunta Krasińskiego, piracko (bez zgody rodziny i Gaszyńskiego) opublikowanych w 1861 roku w Naumburgu przez firmę Johanna Jakoba Maurera.

Surowiej potraktowano dwa z trzech importowanych zbiorów korespondencji poety, które oprócz tego, że dotyczyły problemów życia codziennego (np. kłopotów ze zdrowiem) i spraw związanych z warsztatem pisarskim, zawierały też m.in. sprawozdania z lektur, refleksje filozoficzne, a także rozważania o aktualnych wydarzeniach politycznych, w tym krytyczne uwagi na temat stosunków polsko-rosyjskich. Z trzytomowej lwowskiej edycji Gubrynowicza i Schmidta Listów (t. 1: Listy do Konstantego Gaszyńskiego, 1882; t. 2: Listy do Adama Sottana, 1883; t. 3: Listy do Juliusza Stowackiego, Romana Zatuskiego, Edwarda Jaroszyńskiego, Kajetana i Andrzeja Koźmianów i Bronistawa Trentowskiego, 1887) sprowadzono tylko tomy pierwszy i trzeci, przy czym tom pierwszy zatrzymano w roku wydania, a tom trzeci w 1889 roku. Poza tym w 1912 roku nie dopuszczono do obiegu wydanych w tymże roku we Lwowie Listów do Stanistawa Egberta Koźmiana.

Ze sprowadzonego w 1913 roku dwutomowego wydania Listów do Augusta Cieszkowskiego ${ }^{32}$ nakazano natomiast usunąć tylko kilka stron: $\mathrm{z}$ tomu pierwszego s. 239, a z tomu drugiego - s. 102-103, 107, 265 i 409.

\footnotetext{
${ }^{9}$ Zakwestionowany ustęp pochodzi z listu z 12 marca.

Jest to fragment listu z 16 marca.

${ }^{31}$ Passus pochodzi z listu z 20 marca.

${ }^{32}$ Z Krasiński, Listy [...] do Augusta Cieszkowskiego, t. 1: Listy z lat 1840-1847, t. 2: Listy z lat 1848-1859, wyd. z autografów
} J. Kallenbach, wstęp A. Żółtowski, Kraków-Warszawa 1912. 
W tomie pierwszym zakwestionowano fragment dopisku „(Na osobnej karteczce)" do listu pisanego z Nicei 8 lutego 1847 roku, w którym jest „mowa o ukazie z 6 lutego 1847 r., ogłoszonym przez dzienniki francuskie, a zabraniającym pod srogimi karami propagandy wszelkiego innego wyznania oprócz obrządku grecko-rosyjskiego"33:

Co szczególnego, że ${ }^{*}$ w Warszawie po szpitalach żadnego uśpić eterem Polaka niezdołały chirurgi! - Czy nie fizyologiczne znamię żywotności dzielniejszej, niż u Franków i Germanów? a na co żywotność, jeśli nie na życie?

Straszliwe ukazy o schizmę. - Szybkim krokiem prześladowanie zbliża się do Królestwa i do nas, katolickich właścicieli. Dawna walka Nabuchodonozora z świątynią się odnowi Hieruzalemską!

Czyśs ty uważał, że Trójca moskiewska wiernym Samodzierstwa obrazem na niebie?

Wszystko od Ojca: i Syn i Duch. Syn nic nie oddaje Ojcu, niema krążenia żywota między niemi - akcyi i reakcji, - bo tylko od Ojca pochodzi; zatem i na ziemi tak samo: nic od narodu, nic od poddanych, od wyłonionych nie może wrócić do Rządu - żaden duch nie zawraca z dołu w górę - Auctoritas paterna absolutna. Rząd wszystkiem i na wieki wszystko tworzy i daje, a syn, choć krzyż nosi, choć na krzyżu skona i zmartwychwstanie, jeszcze i wtedy się nie dosłużył życia - nie dostąpił Ducha żadnego. Ojciec wciąż w s z y s t k i e m, bo wszystko dawa, a nic nie odbiera. Wszystko to potworne, to też potwór istnieje na ziemi!*34

Trudno rozsądzić, czy pierwszy akapit pominięto celowo, czy i tym razem był to rezultat mechanicznego usuwania całych stron tekstu.

Dwa kolejne zakwestionowane passusy pochodzą z listu pisanego w Baden 5 stycznia 1849 roku. Pierwszy zawierał historiozoficzne refleksje na temat wolności, równości i braterstwa oraz ostrą krytykę samodzierżawia rosyjskiego:

Sprzeczność wolności t.j. równość nastaje, * równość, a bez braterstwa, równość absolutna i żelazne rózgi po nad nią, bo to jest warunek s i n e qu a n o n, gdy przestaje być idealną, a staje się rzeczywistą. Nim się dostąpi Ludzkości, przejdzie się przez Anty-Ludzkość; nim Królestwa Bożego, ujrzy się Anty-Chrystę; a Anty-Chrysta to będzie Ten, który pojedna Caryzm z bandą infernalną Wrońskiego; który wprowadzi w świat odojczyźnienie ojczyzn i u ludu wszelkiego kupi ojczyznę za strawę, płacąc ludowi strawą. A na to, by módz zapłacić tak, wywłaszczając wszystkich, co własnością dotąd możni, niepodlegli i oświeceni! Car i chłopy - a car carów i chłop chłopów, zlany w jedno, będzie Anty-Chrystą, bo najwyższem zaprzeczeniem osobistości wolnych człowieczych, a tem, że wolnych, wolno miłować się mogących. - Przytem i Boga najwyższem zaprzeczeniem, bo kto przeczy Ludzkości wolnej i miłującej, ten musi i Bogu przeczyć. Dopiero po tem straszliwem zaprzeczeniu wszystkiego, czego żądała ta epoka, ale frazesem tylko, nie sercem, nie myślą, nie czynem istotnym, przemoże się zło.

${ }^{33}$ Cytuję za komentarzem Sudolskiego do tego listu; Z. Krasiński, Listy do Augusta Cieszkowskiego, Edwarda Jaroszyńskiego, Bronisława Trentowskiego, t. 1, oprac. i wstępem poprzedził Z. Sudolski, Warszawa 1988, s. 282.

${ }^{34}$ Idem, Listy [...] do Augusta Cieszkowskiego, t. 1, s. 238-239; początek ingerencji zaznaczony gwiazdką. 
Ludzkość objawi się sobie samej, z przemiary niedoli wyjdzie dobro, z przemiary ateizmu uznanie Boga, z przemiary niewoli wolność i zacznie się iść ku królestwu Bożemu! Lecz powtarzam, my teraz idziem ku Anty-Chryście i wszystko, co tylko się dzieje, fatalnie berło świata coraz bardziej do rąk mu przysuwa. - Ogólnie mówię - w szczegóły się nie wdaję, bo kto o przyszłości mówi, ten wariat, gdy chce anegdotę jej opowiadać, zostawiam to Towiańczykom! Jednak myślę, że Car bieguna północnego połączy w swej osobie dwie osobistości: swoją własną lodowatą, a powtóre stanie się reprezentantem wszystkich Europejskich dążności owych podziemnych, co gwałt i mord i równość absolutną z pod ziemi wyziewają. Rządy wszystkich tajnych podziemności w końcu jemu oddane będą do rąk jako najgodniejszemu! Duchem swym połączy dwie osobistości te, jak Duch Święty łączy Ojca i Syna w Bogu - i to będzie Anty-Bóg. Ojcu odpowie osoba Moskiewska, knutowładna po ojcowsku, Chrystusowi odpowie osoba europejska, puginowładna i socialistowska fałszywie, czyli Anty-chryst. Będzie miło i pięknie!

Oczewiście niedołężność cechą 1848-go, - charakterów nigdzie. Dwóch tylko ludzi było na coś zakrawających, Kawaniak i Jelachich. I ci jeszcze kartaczować musieli niedojrzały lud! O Auguście! Auguście, przekonasz się, czy mój instynkt nerwowy nie czuje barometrycznie przyszłości!

Kościół się nie mylił. Św. Jan dobrze przewidział, że dopiero po Antych-Chryście królestwo Boże nastąpi na ziemi - nie wprzód! Ta postać przepowiedziana bliską nas już, bliską, wierz mi! Biedny Pius IX, jakże związany pod starość, jakżeż przeprowadzon tam, gdzie iśćby niechciał, według słów także św. Jana ${ }^{35}$.

Drugi zaś dotyczył zróżnicowanych losów emigrantów polskich biorących udział w Wiośnie Ludów:

Jednemu tylko zazdroszczę człowiekowi: Jellaczycowi, bo *jednemu się zdarzyło walczyć o niepodległość narodu swego własnego przeciw jego ciemiężcom, na czele siły doskonale uorganizowanej, nie demagogizującej, nie żydowiącej się po Hierozolimsku! Najwyższą to rozkoszą w śmiertelnej piersi być musi! migrantów i schronionych z pod Moskwy do Galicyi, wyprawiają, jednych do Francyi, drugich do Ameryki „z wspaniałomyślności, a nie żądając wdzięczności żadnej”; trzecich, tych co walczą w szeregach Kossutowych, przeznaczają na najsroższą karę nowożytnych czasów za to, że ich zbrodnia najgorsza, t.j. na wydanie Moskwie. Czyś czytał to ogłoszenie rządowe z Krakowa? Moskwa powinnaby się obrazić, bo przez samą Austryę tam wytknięta palcem jako kat najwyższy w świecie! Jako kara śmierci w kodeksie kryminalnym przestępstw Europejskich!

Z Gaety z 24 Dec. miałem od synowca list. - Przesyła mi opis wszystkich zdarzeń od 16 Now. po 1-szy Decembra. - Złote serca, - najgrzeczniejsi ludzie. Myśleć o znajomych i nowego roku im winszować z Gaety! W tych okolicznościach! Odpisałem: wołam, krzyczę, piszę, płaczę, o sobór powszechny błagam i to zwołan do Romy! Wszystko smutnem Auguście!

${ }^{35}$ Ibidem, t. 2, s. 101-103. Uwaga jak w przypisie 34. 
Twierdzą Gaetyści, że nigdy a nigdy nie wrócą za pomocą obcych do Wilczycy, ale dopiero za prośbą łzawą Wilczycy samej. Patrz! Co za impotencya i tam. Mammiani nic a nic nie wskórał ${ }^{36}$.

Inny zakwestionowany fragment pochodził z dopisku do listu pisanego w Heidelbergu 21 kwietnia 1851 roku, w którym poeta, martwiąc się ciężką chorobą synka Władysława, przywoływał losy Jana H. Sierocińskiego (zesłanego za udział w powstaniu listopadowym na Sybir i zakatowanego za zorganizowanie spisku i ucieczkę z zesłania):

[...] ah! Jeśli już tak wola Boża, niechajże wraca ptaszęciem bożym do Nieba; *przynajmniej tego ciałka tak czystego i nadobnego nigdy się nie dotknie knut moskiewski, nigdy i żelazo czerwonych, nie zginie jak przeor Sieraczyński pod 7000 kijów za to, że Polskę kochał”. I śród rozpaczy ta wtóra rozpacz w istocie że była ulgą. Tak żelazo rozpalone, gdy przyłożysz do rany ogromnej, niby to odmianą boleści na chwilkę oszukujesz bolu wiekuistego. I łzy mi się lały wtedy jeszcze gorzkniejsze i mówiłem sobie: „O, nieszczęśliwe plemię, któremu śmierć dzieci wydawać się musi ich wybawieniem ${ }^{37}$.

Cenzura poleciła też usunąć dopisek do listu pisanego z Nicei 17 marca $1847 \mathrm{roku}^{38}$, zamieszczony przez wydawcę we „Fragmentach listów” (s. 409). Poeta ostro polemizował w nim z artykułem Komunistyczne wyznanie wiary w pytaniach i odpowiedziach Mosesa Hessa opublikowanym w „Rheinische Jahrbücher für Gesellschaftlichen Reform" ${ }^{39}$ i umieszczał na jednym poziomie monarchię i komunizm:

I królom i komunistom o to samo chodzi - o władzę nad zwierzęcym rodem ludzkim. Pierwsi mówią: „Nic na ziemi - wszystko w niebie”! co znaczy: „na ziemi daj się knutować bez miary”! Drudzy wrzeszczą: „nic w niebie, wszystko na ziemi!” co znaczy: „rznij drugich, pal, siecz, morduj bez miary”. Wiesz, - jakbym na jednym kołku powiesił jednych, na drugim drugich, a we środku zjawiłby się ukrzyżowany Chrystus - między dwoma łotrami!

Co to za zła wiara i u tych i u tamtych! Czemuż tak skąpią sobie ludzie to Boga, to człowieczeństwa? Czy ich nędzne serca na te dwie miłości nie dość szerokie? Czy tylko zawsze połowicę rzeczy kochać mogą, a drugą nienawidzieć? Mój Boże! Niezawodnie Bóg cierpi, widząc jak Go fałszują, - niezawodnie! Co za szał!

Czytelnicy w zaborze rosyjskim nigdy nie poznali oczywiście politycznych tekstów Krasińskiego, przybierających nierzadko formę listów otwartych. Poeta adresował je do

Ibidem, s. 106-107.

${ }^{37}$ Ibidem, s. 264-265. Gwoli ścisłości trzeba dodać, że na zakwestionowanej s. 265 znalazł się także początek następnego listu (Heidelberg, 1 maja 1851 roku), w którym poeta donosił Cieszkowskiemu m.in. o zysku ze sprzedaży poznańskiej edycji Irydiona i o spotkaniu rodzinnym. Ingerencja ta wydaje się kolejnym przykładem mechanicznego zakazywania całych stron.

${ }^{38}$ Datę ustalił Sudolski. Zob. Z. Krasiński, Listy do Augusta Cieszkowskiego, t. 1, s. 300-301.

${ }^{39}$ Ibidem, s. 302. 
Charles'a de Montalemberta, Alphonse'a de Lamartine' $a^{40}$, François Guizota, Piusa IX, Napoleona III i wielkiej księżny badeńskiej - Stefanii ${ }^{41}$.

Jedyną edycją korespondencji poety w zaborze rosyjskim był warszawski zbiór przygotowany przez Leopolda Wellischa Zygmunt Krasiński i Ary Scheffer, opublikowany w 1909 roku w pięćdziesiątą rocznicę zgonu poety. Tę bardzo starannie wydaną książkę, której „wytłoczono 615 liczbowanych egzemplarzy, z których pierwsze 25 na papierze czerpanym", ozdobioną reprodukcjami dzieł artysty (m.in. portretami poety, Potockiej, Krasińskiej, Fryderyka Chopina) i podobiznami listów, zawierającą piętnaście listów Krasińskiego do holenderskiego malarza, a także dwie korespondencje Scheffera, dopuszczono do obiegu bez żadnych skreśleń, gdyż dotyczyły one tylko zagadnień związanych ze sztuką.

Jeśli chodzi o listy Słowackiego pisane do rodziny (głównie do matki Salomei Słowackiej oraz do wujostwa Hersylii i Teofila Januszewskich), jak też do przyjaciół (np. Wojciecha Statllera i Krasińskiego), to cenzura rosyjska ingerowała w nie sporadycznie. Dotyczyły one bowiem głównie spraw codziennych (np. bytowych czy zdrowotnych) oraz problemów związanych z byciem pisarzem (np. zmagań twórczych i kłopotów wydawniczych), a także zawierały relacje i wspomnienia z podróży.

Gdy w 1876 roku rozpatrywano pierwsze wydanie Listów do matki (Lwów 1875$-1876)^{42}$, tom pierwszy dopuszczono w całości, a z tomu drugiego polecono usunąć dwa fragmenty. Jeden pochodził z listu do matki (Paryż, 29 sierpnia 1848 roku), w którym poeta wyrażał swe zaniepokojenie wydarzeniami w kraju związanymi z Wiosną Ludów:

Widzisz, droga moja, że mi dobrze idzie na ziemi; rodziny się zaczynają, w których pamięć moja potrwa, dla których wspomnienie ducha mego nie będzie obojętne. W tej chwili odbieram list z Krakowa od jednego z młodych moich, w którym wyczytuję mnóstwo wieści o zaburzeniach w cesarstwie ross. List ten byłby mię bardzo zgorączkował nadzieją, gdyby nie data, która mi pokazuje, że te wszystkie wieści są tylko kameleonem na mgłach północnych, promieniejącym się w kolory cudowne. Ty wiesz droga, że ja światłości, nie kolorów czekam. Pisz najdroższa jak najczęściej teraz, bo mię cholera czyni często niespokojnym o was... Wszakże wypytując głębiej

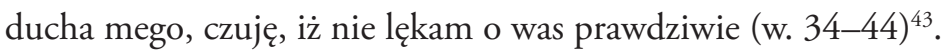

Drugi zakwestionowany fragment (s. 222) to zakończenie listu do wspomnianego wuja poety - Januszewskiego (Paryż, 9 października 1848 roku):

${ }^{40}$ Dwie słynne odezwy zatytułowane Listy Zygmunta Krasińskiego do Hr. Montalemberta i A. Lamartina opublikowała po raz pierwszy w formie książkowej w 1881 roku poznańska Księgarnia Jana Chociszewskiego. Edycji tej nie sprowadzono jednak do Królestwa Polskiego.

${ }^{41}$ Co prawda, opublikowano je (po francusku i w przekładzie na język polski) w tomie siódmym jubileuszowego wydania Pism opracowanych przez Jana Czubka (Kraków-Warszawa 1912), jednak edycji tej nigdy nie próbowano sprowadzić do Królestwa Polskiego. Ze spreparowanego wydania tychże Pism, przeznaczonego do rozpowszechniania w zaborze rosyjskim, teksty te wydawca usunął natomiast sam.

${ }^{42}$ Edycja zawierała też listy do wujostwa Januszewskich.

${ }^{43}$ W sprowadzonych w roku wydania Listach do matki (Lwów 1883) passusu tego już nie zakwestionowano. W komentarzu Eugeniusza Sawrymowicza do cytowanego fragmentu (J. Słowacki, Korespondencja, t. 2, oprac. E. Sawrymowicz, Warszawa 1963, s. 213) czytamy: „Od kogo był ów list, nie wiadomo; znajdowała się w nim zapewne wiadomość o wykryciu w Rosji spisku Pietraszewców. [...] Nie o cholerę oczywiście chodziło, tylko o represje w Galicji w związku z szerzeniem się ruchów rewolucyjnych i narodowowyzwoleńczych w monarchii austriackiej". Wszystkie numery wersów podaję za tą edycją. 
Dlatego to, Filu mój, nie czułem się dość mocny, abym *wpadł w to morze ciężkie i ołowiane, a jednak niby wzruszone i wałami swoimi gdzieś niby naprzód idące. Jeszcze nie czas na południowe prowincje. Ale już słońce wschodzi dla Polski.

Chciałbym o tym wszystkim obszerniej z tobą pomówić choć listownie i spodziewam się, że nieco wolniejszy w zimie, pozwolisz mi obszerniejszej ze sobą korespondencji. Teraz nie wiem, czy cię ten list dojdzie, boście mi adresu swego nie dali, a poste restante listy pisane, wiem, że często przez was reklamowane nie są - daj mi więc, proszę, adres nowy i powiedz mi, czy do ciebie pisane listy do Matki mojej pójdą, czy zaś osobno do niej w listach twoich drugie listki zawierać mogę. Zawsze proszę cię, abyś listy rozpieczętowywał i patrzył, co do niej? a co do ciebie? Mogą być albowiem różne rzeczy, które, nie do ukrywania przed nią (bo nigdy kłamać nic Matce nie mogę), ale potrzebuję wszakże mniej śmiałego języka.

Dziękuję ci za pomówienie z księgarzem; w zyskach jego nic nie chciej zmniejszać, owszem, staraj się, aby miał zyski znaczne, które by go do rozsyłania znęciły.

Ściskam ciebie i Sylki kochanej nóżki całuję.

Jul (w. 45-65) ${ }^{44}$

Ingerencja ta jest kolejnym przykładem mechanicznego działania cenzorów. Można bowiem przypuszczać, że tak naprawdę zastrzeżenia urzędnika wzbudziły jedynie zdania: „Jeszcze nie czas na południowe prowincje. Ale już słońce wschodzi dla Polski”. Sugestię tę potwierdza to, że sprowadzone do Królestwa Polskiego w 1883 roku spreparowane Listy (wyd. 2 pomn., Lwów 1883), w których wydawca opuścił owe dwa zdania, cenzura zagraniczna dopuściła do obiegu bez żadnych skreśleń.

W całym badanym okresie w Warszawie ukazały się zaledwie trzy zbiorki korespondencji poety, przy czym cenzura ingerowała tylko w liczące zaledwie osiem tekstów Listy Juliusza Stowackiego do pani Joanny Bobrowej (Warszawa 1896). W liście (Paryż, 14 maja 1842 roku), w którym znalazł się zaimprowizowany „na ostatnią pamiątkę” wiersz potępiający brak patriotyzmu adresatki, zakwestionowano dwa fragmenty:

Lecz nie powiodę do takiego zdroja,

Bo teraz straszna jest ducha kaskada;

To cały duch mój i cała krew moja,

Która na Polskę chce upaść - i spada.

Raz ty porwana tym strumieniem gminnym,

Byłabyś nigdy nie wróconą światu,

Dlatego poszłaś gdzie indziej - z kim innym,

Ręki się bojąc dać dawnemu bratu.

Bo dzisiaj Polka ciekawość pokona,

A jej nie karmi to, co tłum paryski.

Gdy w sercu Polska duchem urodzona

Jak Nimfa wstaje z perłowej kołyski (w. 41-52).

${ }^{44}$ Eugeniusz Sawrymowicz (ibidem, s. 224) obawy poety o to, że list jego nie dojdzie do adresata, wyjaśnia następująco: „Sprawa nie jest jasna: mogłoby się wydawać, że z powodu napiętej sytuacji we wschodniej Galicji (podniecenie rewolucyjne, które w miesiąc później doprowadzi do powstania ludowego we Lwowie i do bombardowania miasta przez wojska austriackie) Januszewscy przenieśli się z Ubienia do Lwowa i że dlatego Słowacki nie miał ich adresu". 
Bo to okropnie! rany pozamykać,

Zagoić wszystkie dawne serca blizny! -

Iść - i aniołów już nie napotykać!

Już nie mieć ani serca! - ni Ojczyzny! (w. 65-68)

Natomiast brak początku w innym liście (Paryż, 15 lipca 1842 roku):

Na próżno mi Pani zakazujesz odpisywać na przemazaną liniją Jej listu - cały list jest tyko liniją - a ja stwierdziłbym tylko mniemanie Pani, żem jest człowiekiem bez serca, gdybym na tę serdeczną i smutną skargę nie odpisał. Długo byłem także bez odpowiedzi i bez żadnej o nim wiadomości (w. 1-5)

- wynikał prawdopodobnie z decyzji wydawcy.

W dwóch identycznych pod względem zawartości Wyborach listów, które ukazały się w 1911 roku w tanich seriach „Biblioteczka Narodowa” i „Książi dla Wszystkich”, opublikowano - jak twierdził w przedmowie Henryk Galle - jedynie

Wydawca usuwał rozmaite nieważne, jego zdaniem, dopiski na końcu listów
50, nie najpiękniejszych zapewne, bo wszystkie są równie piękne, ale najciekawszych ze względu na opowiedziane w nich wypadki: tak więc najwięcej poświęciliśmy epoce szwajcarskiej (1833-1835) i podróży na Wschód (1837-1837)

przy czym czasem opuszczano ich fragmenty. $\mathrm{O}$ tym, że nie wynikało to z przyczyn cenzuralnych, świadczy, po pierwsze, to, że wyboru listów dokonano na podstawie edycji: Listy, t. 1-2, z autografów wydał po raz pierwszy L. Méyet, Lwów $1899^{46}$, którą dwukrotnie - w latach 1899 i 1913 - dopuszczono do rozpowszechniania bez żadnych skreśleń ${ }^{47}$; a po drugie, że przywoływany wcześniej list do wuja opublikowano tu w całości. Jak sądzę, to wydawca - kierując się względami estetycznymi - arbitralnie zrezygnował z niektórych passusów. Pisał on bowiem:

Wreszcie, jeden jest jeszcze wzgląd, który skłonił nas do ogłoszenia tego „Wyboru listów" [...], to cudna forma tych listów. To nie jest korespondencya człowieka przeciętnego, przepełniona błahostkami codziennego bytu, ciekawa tylko dla adresata i tylko do chwili bieżącej; to listy poety, który i tutaj, w osobistych zwierzeniach do ukochanej matki, nie przestał być poetą, a od prozy życia był w każdym czynie tak bardzo daleki. To też każdy niemal list jego - to poemat $[\ldots]^{48}$.

Bez trudu da się stwierdzić, że pominięte fragmenty dotyczyły głównie osób nieznanych przeciętnemu czytelnikowi oraz czynności codziennych i mało istotnych zdarzeń. Poza tym wydawca usuwał rozmaite nieważne, jego zdaniem, dopiski na końcu listów.

${ }^{45}$ J. Słowacki, Wybór listów, cz. 1, Warszawa 1911, s. 4 („Biblioteczka Narodowa”). W rzeczywistości jednak oba zbiory zawierały po siedemdziesiąt trzy listy, przy czym w części pierwszej opublikowano ich dwadzieścia trzy (pisane od 15 września 1830 roku do 1 kwietnia 1835 roku), a w cześci drugiej - piećcdziesiąt (od 30 czerwca 1835 roku do 4 marca 1849 roku).

${ }^{46}$ Świadczy o tym numeracja wybranych listów, identyczna z numerami nadanymi przez Méyeta.

${ }^{47}$ Listy te, uzupełnione o Notatki z podróży po Palestynie i Syrii, zamieścił też Tadeusz Pini w tomie drugim Dzieł Słowackiego (Lwów [1909]), dopuszczonych do obiegu w lipcu 1914 roku.

${ }^{48}$ J. Słowacki, Wybór listów, s. 6-7. 
W ofercie wydawniczej dokonań poszczególnych pisarzy edycje ich korespondencji zajmowały niewielką część (niespełna 6\%): w wypadku Mickiewicza - 5,8\%, Krasińskiego - 5,65\%, a Słowackiego - 5,6\%, przy czym czytelnicy w zaborze rosyjskim mieli dostęp tylko do ich części: edycje miejscowe były bowiem nieliczne, nie podjęto też prób sprowadzenia ponad połowy $(56,25 \%)$ z dwudziestu siedmiu wydań zagranicznych lub zakordonowych. Najłagodniej cenzura potraktowała spuściznę epistolograficzną Słowackiego. Z piętnastu (w tym z trzech warszawskich) wydań jego korespondencji na rynku królewiackim była dostępna blisko połowa (siedem), przy czym cenzura okaleczyła - zresztą nieznacznie - tylko trzy z nich (w tym jedno wydanie warszawskie). $\mathrm{Z}$ dwudziestu trzech importowanych edycji korespondencji Mickiewicza próbowano sprowadzić co prawda ponad połowę (trzynaście), ale do rozpowszechniania trafiło zaledwie osiem (34,8\% wszystkich), w tym pięć z drobnymi ingerencjami cenzorskimi. Najsurowsza okazała się cenzura wobec korespondencji Krasińskiego: z dziesięciu osobnych edycji jego listów do oficjalnego obiegu trafiły jedynie cztery wydania (w tym w wersji pełnej tylko jedna edycja - warszawska).

Mimo to można stwierdzić, że listy poetów kwestionowano relatywnie rzadko. Jak się wydaje, autocenzura stosowana przez autorów oraz selekcja materiału epistolarnego przez wydawców okazały się skuteczne. Cenzorzy usuwali w całości tylko listy będące $\mathrm{w}$ istocie manifestami politycznymi oraz nieliczne dotyczące m.in. powstań narodowych, walk narodowowyzwoleńczych, utworów uznanych wcześniej za teksty niecenzuralne, a przede wszystkim passusy zawierające nieprzychylne uwagi na temat carskiej Rosji, religii prawosławnej i godzące w samodzierżawie.

Najłagodniej

cenzura potraktowała spuściznę epistolograficzną Słowackiego

\section{Edycje listów wielkich poetów romantycznych}

Wykaz obejmuje polskojęzyczne edycje zbiorów korespondencji każdego z poetów w układzie chronologicznym. W opisach uwzględniono poza tytułem numer tomu, nazwisko i imię osoby opracowującej, miejsce i rok wydania, nakładcę, drukarza, nazwę i numer serii oraz podano informację o losach edycji w zaborze rosyjskim ${ }^{49}$.

\section{Adam Mickiewicz}

1. Korespondencja, w: Pisma, t. 6, wyd. nowe zup., Paryż 1861 [Wolff M.B.];

Martinet L. [druk.] (w latach sześćdziesiątych tom dopuszczony do obiegu warunkowo).

2. Korespondencja, w: Pisma, t. 6, wyd. nowe zup., Paryż-Lipsk 1861, Jung-Treuttel E., Wegner F.; Martinet L. [druk.] (wydania nie sprowadzono).

3. Korespondencja, w: Pisma, t. 5, wyd. nowe zup., Lipsk 1862, Brockhaus F.A.; Brockhaus F.A. [druk.], „Biblioteka Pisarzy Polskich”, t. 12, 59 (w latach sześćdziesiątych publikacja zakwestionowana w całości).

${ }^{49}$ Format opisu przejęto z pracy: J. Kostecki, M. Rowicka, Granice wolności słowa w zaborze rosyjskim w latach 1865-1904. Wykaz publikacji polskojęzycznych zakwestionowanych oraz dopuszczonych do obiegu przez carską cenzurę zagraniczną, t. 1-3, Warszawa 2006. 
4. Listy śp. Adama Mickiewicza do Pani Konstancji, Poznań 1863 b.n.; Merzbach L. [druk.] (w 1867 roku publikacja zakwestionowana w całości).

5. Korespondencya, t. 1-2, wyd. 1, Paryż 1870-1872, Księgarnia Luksemburska; Bracia Rouge, Dunon i Fresné [druk.] (w 1875 roku sprowadzono tom drugi, który zakwestionowano w całości; w 1876 roku sprowadzono oba tomy, przy czym tom pierwszy dopuszczono do obiegu warunkowo, a tom drugi - w całości; w 1906 roku oba tomy sprowadzono ponownie i tym razem dopuszczono w całości).

6. Korespondencya, t. 1-2, wyd. 2, Paryż 1871-1872, Księgarnia Luksemburska; Bracia Rouge, Dunon i Fresné [druk.] (w 1873 roku oba tomy dopuszczono do obiegu w całości, w 1875 roku oba tomy zakwestionowano w całości).

7. Korespondencya, t. 1-3, wyd. 3, Paryż 1875-1876, Księgarnia Luksemburska; Bracia Rouge, Dunon i Fresné [druk.] (w 1875 roku sprowadzono tomy pierwszy i drugi, oba zakwestionowano w całości).

8. Korespondencya, t. 1-3, wyd. 4, Paryż 1874-1876, Księgarnia Luksemburska; Bracia Rouge, Dunon i Fresné [druk.] (w 1881 roku sprowadzono tomy pierwszy, drugi i trzeci; tomy pierwszy i drugi dopuszczono do obiegu warunkowo, a tom trzeci w całości).

9. Korespondencja, w: Pisma, t. 5, wyd. nowe zup., Lipsk 1876, Brockhaus F.A.; Brockhaus F.A. [druk.], „Biblioteka Pisarzy Polskich”, t. 12, 59 (wydania nie sprowadzono).

10. Wspótudziat Adama Mickiewicza w sprawie Towiańskiego. Listy i przemówienia, t. 1-2, Paryż 1877, Księgarnia Luksemburska; Tolmer I.J. [druk.] (w 1879 roku publikacja zakwestionowana w całości).

11. Wspótudziat Adama Mickiewicza w sprawie Towiańskiego. Listy i przemówienia, t. 1-2, Lwów 1880, Gubrynowicz i Schmidt (wydania nie sprowadzono).

12. Korespondencya, t. 1-3, wyd. 4, Paryż-Lwów 1880, Księgarnia Luksemburska, Gubrynowicz i Schmidt Księgarnia; Bracia Rouge, Dunon i Fresné [druk.]; t. 4, 1885 Księgarnia Luksemburska; Zabieżyna wdowa [druk.] (wydania nie sprowadzono).

13. Korespondencya Adama Mickiewicza, w: Dzieta, t. 7-11, wyd. zup. przez dzieci aut. dokonane, Paryż 1880-1885, Księgarnia Polska Zabieżyny A.; Bracia Rouge, Dunon i Fresné [druk.] (w 1881 roku sprowadzono tomy siódmy-dziewiąty, które warunkowo dopuszczono do obiegu. W 1885 roku sprowadzono tomy dziesiąty-jedenasty: tom dziesiąty zakwestionowano w całości, a tom jedenasty warunkowo dopuszczono do obiegu).

14. Korespondencja, w: Pisma, t. 5, wyd. nowe zup., Lipsk 1889, Brockhaus F.A.; Brockhaus F.A. [druk.], „Biblioteka Pisarzy Polskich”, t. 12, 59 (w 1909 roku tom zakwestionowano w całości).

15. Korespondencja, w: Pisma, t. 5, wyd. nowe zup. w pięciu tomach, Lipsk 1897, Brockhaus F.A.; Brockhaus F.A. [druk.] (edycja spreparowana przez wydawcę, w 1897 roku dopuszczona do obiegu w całości).

16. Wybór listów, Kallenbach Józef [uł.], Kraków 1899, Spółka Wydawnicza Polska; „Czas” [druk.], „Nowa Biblioteka Uniwersalna” (edycja spreparowana przez wydawcę, w 1899 roku dopuszczona do obiegu w całości).

17. Korespondencja, w: Pisma, t. 5, wyd. nowe zup., Chicago Ill. 1905, Dyniewicz W.; Dyniewicz W. [druk.] (wydania nie sprowadzono). 
18. Korespondencja, w: Pisma, t. 5, wyd. nowe zup., Chicago Ill. [1910], Polish American Publishing Company; Polish American Publishing Company [druk.] (wydania nie sprowadzono).

19. Nieznane pisma Adama Mickiewicza. Z archiwum filomatów, Kallenbach Józef [wyd.], Kraków-Warszawa 1910, Gebethner G. i Sp., Geberhner i Wolff; Uniwersytet Jagielloński [druk.] (w 1909 roku publikacja dopuszczona do obiegu w całości).

20. Listy i przemówienia, w: Dzieta, t. 3, Reiter Marian [wyd.], Lwów-Kraków-New York-Warszawa [1911-1913], Altenberg H. Księgarnia; Narodowa [druk.]; Wende i Sp. (T. Hiż i A. Turkuł), The Polish Book Importing [skł. gł.], „Biblioteka Klasyków Polskich", t. 6 (wydania nie sprowadzono).

21. Listy i przemówienia, w: Dzieta, t. 3. Reiter Marian [wyd.], Lwów-Kraków-New York-Warszawa [1911-1913], Altenberg H. Księgarnia; Narodowa [druk.]; Wende i Sp. (T. Hiż i A. Turkuł), The Polish Book Importing [skł. gł.], „Biblioteka Klasyków Polskich", t. 6 (spreparowany wariant edycji poprzedniej; wydania nie sprowadzono).

22. Listy i przemówienia, w: Dzieta wszystkie, t. 10-12, Pini Tadeusz, Marian Reiter [wyd. i objaśn.], Lwów-Kraków 1912, Altenberg H. Księgarnia; Narodowa [druk.] (wydania nie sprowadzono).

23. Korespondencja, w: Pisma, t. 5, wyd. nowe zup., Poznań-Charlottenburg-Lipsk 1912, Knaster St.H. Księgarnia Wysyłkowa; Brockhaus F.A. [druk.], „Biblioteka Poetów i Pisarzy Polskich", t. 5 (wydania nie sprowadzono).

\section{Fuliusz Stowacki}

1. Listy do matki, t. 1-2, Lwów 1875-1876, Gubrynowicz i Schmidt Księgarnia; Piller K. [druk.] (w 1876 roku publikacja dopuszczona do obiegu: tom pierwszy w całości, tom drugi warunkowo).

2. Listy do matki, t. 1-2, Lwów 1875-1876, Gubrynowicz i Schmidt Księgarnia; Piller K. [druk.] (zawartość edycji ta sama jak poprzedniej. Różni się od niej kartą tytutową, brakiem nazwy drukarza, innym sposobem wydrukowania przedmowy w tomie pierwszym. Wydania nie sprowadzono).

3. Listy do matki, t. 1-2, Lwów 1875-1876, Gubrynowicz i Schmidt Księgarnia; Piller K. [druk.] (edycja spreparowana przez wydawcę, wydania nie sprowadzono).

4. Listy, t. 1-2, wyd. 2 znacznie pomn., Lwów-Cieszyn 1883, Gubrynowicz i Schmidt Księgarnia; Prochaska K. [druk.] (w 1883 roku publikacja dopuszczona do obiegu w całości).

5. Listy, t. 1-2, wyd. 3 znacznie pomn., Lwów-Cieszyn 1883, Gubrynowicz i Schmidt Księgarnia; Prochaska K. [druk.], „Biblioteka Polska”, t. 38-39 (wydania nie sprowadzono).

6. Listy do pani Joanny Bobrowej, Weyssenhoff Józef (J.W.) [wyd.], Warszawa 1896, osobna odbitka z „Biblioteki Warszawskiej”; Sikorski J. [druk.].

7. Listy, Méyet Leopold [z autogr. wyd. po raz pierwszy], t. 1-2, Lwów-Cieszyn 1899, Księgarnia Polska; Prochaska K. [druk.], „Biblioteka Księgarni Polskiej”, t. 26-27 (edycja dopuszczona do obiegu w całości w latach 1899 i 1913).

8. Pamiętniki. Listy do matki i rodziny, w: Dzieta, t. 2, Pini Tadeusz [wyd.], Lwów-Kraków [1909], Altenberg H. Księgarnia; Narodowa [druk.], „Biblioteka Klasyków Polskich", t. 2 (wydania nie sprowadzono). 
9. Pamiętniki. Listy do matki i rodziny, w: Dzieta, t. 2, Pini Tadeusz [wyd.], Lwów-Kraków [1909], Altenberg H. Księgarnia; Narodowa [druk.], „Biblioteka Klasyków Polskich", t. 2 (zeszytowy wariant edycji poprzedniej, wydania nie sprowadzono).

10. Pamiętniki. Listy do matki i rodziny, w: Dzieta, t. 2, Pini Tadeusz [wyd.], Lwów-Kraków [1909], Altenberg H. Księgarnia; Narodowa [druk.], „Biblioteka Klasyków Polskich", t. 2 (w 1914 roku edycja dopuszczona do obiegu w całości).

11. Pamiętniki. Listy do matki i rodziny, Lwów-Warszawa-New York-Kraków [1909], b.n.; Drukarnia Narodowa [druk.]; Księgarnia H. Altenberga, Wende i Sp. (T. Hiż i A. Turkuł), The Polish Book Importing Co. [skł. gł.] (wydania nie sprowadzono).

12. Listy wszystkie zebrane, w: Poezye. Pisma pośmiertne wydane w setna rocznice narodzin poety, Kantak Kamil Juliusz [zebr.], t. 9-10, Mikołów 1909-1910, Miarka K.; Miarka K. [druk.], „Nowa Biblioteka Pisarzy Polskich”, t. 23-24 (wydania nie sprowadzono).

13. Korespondencya Juliusza Stowackiego to jest listy do matki i wszystkie inne, wyd. zup. pierwsze illustr. w setną rocznicę urodzin poety, Kantak Kamil Juliusz [zebr.], t. 1-2, Mikołów-Warszawa 1910, Miarka K.; Miarka K. [druk.] (wydania nie sprowadzono).

14. Wybór listów, Galle Henryk [wyd.], cz. 1-2, Warszawa 1911, Arct M.; Arct M. [druk.], „Biblioteczka Narodowa”, nr 44-45.

15. Wybór listów, Galle Henryk [wyd.], cz. 1-2, Warszawa 1911, Arct M.; Arct M. [druk.], „Książki dla Wszystkich”, nr 536-537.

Zugmunt Krasinski

1. Listy Zygmunta Krasińskiego o poemacie Kajetana Koźmiana „Stefan Czarniecki”, poprzedzone wstępnem słowem i życiorysem, Poznań 1859, Żupański J.K.; Merzbach L. [druk.] (wydania nie sprowadzono).

2. Wyjątki z listów Zygmunta Krasińskiego, Gaszyński Konstanty [przedm.], t. 1, Paryż 1860, Księgarnia Polska; Martinet L. [druk.] (w latach sześćdziesiątych publikacja dopuszczona do obiegu warunkowo).

3. Wyjątki z listów Zygmunta Krasińskiego, Gaszyński Konstanty [przedm.], t. 1, wyd. nowe, Paryż-Naumburg 1861, Maurer J.J.; Paetz G. [druk.] (w latach sześćdziesiątych publikacja dopuszczona do obiegu warunkowo).

4. Listy Zygmunta Krasińskiego od roku 1835 do 1844 pisane do Edwarda Jaroszyńskiego, Gorzkowski Marius [ogłosił z oryginałów znalezionych niedawno w Hajsyńskim powiecie we wsi Hruźce na Podolu], Kraków 1871, Gorzkowski M.; "Czas” [druk.] (wydania nie sprowadzono, nakład skonfiskowała rodzina).

5. Listy Zygmunta Krasińskiego do Hr. Montalamberta i A. Lamartina, Radońska Teofila [przekł. z franc.], Poznań 1881, Księgarnia J. Chociszewskiego; Chocieszyński F. [druk.] (wydania nie sprowadzono).

6. Listy Zygmunta Krasińskiego, z portr. Autora, Kraszewski Józef Ignacy [przedm.], Lwów-Kraków 1882-1887, Gubrynowicz i Schmidt Księgarnia; Anczyc W.L. [druk.]

- t. 1 [1882]: Listy do Konstantego Gaszyńskiego.

- t. 2 [1883]: Listy Do Adama Sottana.

- t. 3 [1887]: Listy do Juliusza Stowackiego, Romana Zatuskiego, Edwarda Jaroszyńskiego, Kajetana i Andrzeja Koźmianów i Bronistawa Trentowskiego. 
W 1882 roku sprowadzono tom pierwszy, a w 1889 roku - tom trzeci. Obu wydań nie dopuszczono do obiegu. Tomu drugiego nie sprowadzono.

7. Listy Zygmunta Krasińskiego do Stanistawa Matachowskiego, Kraszewski Józef Ignacy [wyd.], Kraków 1885, „Czas”; „Czas” [druk.] (wydania nie sprowadzono).

8. Listy z nieznanych rękopisów (Zygmunt Krasiński i Ary Scheffer), Wellisch Leopold [wyd., wstępem i przyp. opatrzył], Warszawa 1909, Wydawca; Tow. Akc. S. Orgelbranda s-ów [druk.]; Księgarnia E. Wendego i Sp. (T. Hiż i A. Turkuł) [sgł.].

9. Listy Zygmunta Krasińskiego do Stanistawa Egberta Koźmiana, Lwów 1912, Towarzystwo Literackie im. A. Mickiewicza; Drukarnia Polska [druk.] (w 1912 roku publikacji nie dopuszczono do obiegu).

10. Listy Zygmunta Krasińskiego do Augusta Cieszkowskiego, Kallenbach Józef [z autogr. wyd.], Żółtowski Adam [wstęp], Kraków-Warszawa 1912, Gebethner G. i Sp., Gebethner i Wolff; Drukarnia Uniwersytetu Jagiellońskiego [druk.] (w 1913 roku publikacja dopuszczona do obiegu warunkowo).

Key Words: Adam Mickiewicz, Juliusz Słowacki, Zygmunt Krasiński, $19^{\text {th }}-20^{\text {th }}$ centuries, correspondence editions, censorship

Abstract: The study reconstructs the attitude of Russian censorship to the published correspondence of Adam Mickiewicz, Juliusz Słowacki and Zygmunt Krasiński. It presents the examples of self-censorship used by the poets themselves, the practice of censoring writers' letters by their families and publishers' ways of preparing epistolary collections for printing. The analysis focuses on the deletions and changes made by censors in these collections of letters, which were to be published in the Russian partition or imported from the outside. The paper describes the editions which were not allowed to be distributed at all, these publications which were allowed to be distributed after removal of the some passages, but also the books which could be spread unreservedly. 